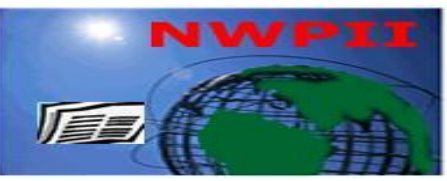

American Journal of Biomedical Sciences

ISSN: 1937-9080

nwpii.com/ajbms

\title{
Recent Advances in Gold(I) Complexes Based Biological Applications
}

\section{Tong Shu, ${ }^{1}$ Lei Su, ${ }^{1}$ Shu-Feng Zhou ${ }^{2}$, Khalid A. Al-Ghanim ${ }^{3}$, Shahid Mahboob ${ }^{3}$, Bunshi Fugetsu ${ }^{4}$, Xueji Zhang ${ }^{1, *}$}

${ }^{1}$ Research Center for Bioengineering and Sensing Technology, School of Chemistry and Biological Engineering, University of Science and Technology Beijing, Beijing, China

${ }^{2}$ Department of Pharmaceutical Science, College of Pharmacy, University of South Florida, Tampa, FL 33612, USA

${ }^{3}$ Department of Zoology, College of Science, King Saud University, P.O. Box 2455, Riyadh-11451, Saudi Arabia.

${ }^{4}$ Policy Alternative Research Institute, The University of Tokyo, Faculty of Engineering Bldg. 9, 2-11-16 Yayoi,

Bunkyo-ku, Tokyo 113-0032, Japan

"Corresponding Author

Prof. Xueji Zhang

Research Center for Bioengineering and Sensing Technology

School of Chemistry and Biological Engineering

University of Science and Technology Beijing

Beijing 100083, China

Email: zhangxueji@ustb.edu.cn

Received: 29 September 2015; | Revised: 18 October 2015; | Accepted: 2 November 2015

\begin{abstract}
The development of the synthesis of a wide range of $\mathrm{Au}(\mathrm{I})$ complexes reversibly promotes the advance in their practical usages, particularly, in biological applications. The formation of gold-sulfur rich protein adducts contributes to the cytotoxic nature of the gold compounds for chemotherapeutic approaches, while $\mathrm{Au}-\mathrm{Au}$ interactions endow them with spectroscopic and luminescence properties. This article reviews that the recent five year progress for $\mathrm{Au}(\mathrm{I})$ complexes based biological applications, including the investigation of the development of new anticancer agents and antibacterial compounds, the application of biological imaging and the fabrication of novel sensors.
\end{abstract}

Keywords: $\mathrm{Au}(\mathrm{I})$ complexes, anticancer, antibacterial, biological imaging, sensors

\section{Introduction}

$\mathrm{Au}(\mathrm{I})$ complexes are attractive and key compounds in gold chemistry, bridges between elemental gold and gold nanomaterials. Advances in coordination chemistry enhance the development of $\mathrm{Au}(\mathrm{I})$ complexes and result in a variety of novel $\mathrm{Au}(\mathrm{I})$ complexes. The featured $\mathrm{Au}-\mathrm{Au}$ bonds (aurophilicity) in $\mathrm{Au}(\mathrm{I})$ complexes give an fresh impetus to form unique fascinating structure and possess luminescence properties. 
The intra- and inter- Au-Au binding interactions guarantee the stability of supramolecular structures, such as $\mathrm{Au}_{16}$ macrocycle[1], $\mathrm{Au}_{12}$ capsule and $\mathrm{Au}_{36}$ crown[2]. The aurophilic interaction of $\mathrm{Au}(\mathrm{I})$ complexes is also responsible for their unique photophysical properties. Recently, some excellent studies on $\mathrm{Au}(\mathrm{I})$ complexes have demonstrated that the special luminescence phenomenon of $\mathrm{Au}(\mathrm{I})$ complexes is assigned to aggregation induced emission (AIE) $[3,4]$. AIE, exactly opposite to traditional aggregation caused quenching (ACQ)[5], was firstly reported by Tang et.al in 2001[6]. They found that a series of propeller-shaped organic molecules emitted bright fluorescence in condensed phase, even in solid states. Then, the concept of AIE has permeated other materials, such as transition metal complexes. In 2012, Xie et.al firstly introduced AIE into Au(I) complexes, which are driven by aurophilic interaction and similarly emit in aggregation state[3]. Interestingly, different from typical organic molecular, $\mathrm{Au}-\mathrm{Au}$ interactions endow $\mathrm{Au}(\mathrm{I})$ complexes with larger Stoker shifts, longer luminescence lifetimes and wavelength-tunable emissions. Due to metal centered triplet state, the emission of $\mathrm{Au}(\mathrm{I})$ complexes usually show phosphorescence properties. Moreover, the maximum emissions of $\mathrm{Au}(\mathrm{I})$ complexes change with the interactive distance of $\mathrm{Au}-\mathrm{Au}$ [7].

Because of capabilities mentioned above, $\mathrm{Au}(\mathrm{I})$ complexes increasingly display practical potentials as promising candidates for bioluminescence materials. In the present review, we'll focus our discussions on the recent five years advances in bio-applications of $\mathrm{Au}(\mathrm{I})$ complexes, concluding to four directions, including anticancer, antibacterial, bioimaging and sensing applications. Besides applications of $\mathrm{Au}(\mathrm{I})$ complexes in imaging and sensing, we cover their utilities in antibacterial and anticancer, The former two directions derive from their cytotoxic nature, while the other two are mainly based on the luminescence properties. We also address the outlook and the challenge of future developments in this promising field.

\section{Anticancer Study of Au(I) Complexes}

Recently, a variety of $\mathrm{Au}(\mathrm{I})$ complexes have undergo the assessment of anticancer activity and the majority of them belongs to monometallic and bimetallic complexes. It's deduced that supermolecular or polymeric structures are avoided as the results of maintaining aqueous solubility and lipophilic moiety for the cell uptake at the same time. Therefore, usually the most common forms in therapeutic application are discrete molecular species.

Auranofin (thiolate-Au-PEt ${ }_{3}$ complex, typical antiarthritic mononuclear $\mathrm{Au}(\mathrm{I})$ drug exhibits promising potentials as gold related anticancer agents[8]. Within this context, auranofin analogues (thiolate-Au-tertiary phosphine derivatives) have been explored to extend the variety of and improve the anticancer performance of $\mathrm{Au}(\mathrm{I})$ complexes. Gimeno et al. investigated a series of $\mathrm{Au}(\mathrm{I})$ complexes containing various bio-inspired amino acids modified ligands[9]. As shown in Fig. 1, they first obtained the precursor compound, nicotinic acid thiolate gold complex $\left[\mathrm{Au}(\mathrm{SpyCOOH})\left(\mathrm{PPh}_{3}\right)\right]$ via the reaction of $\left[\mathrm{AuCl}\left(\mathrm{PPh}_{3}\right)\right]$ with mercaptoniconitic acid. The acid moiety of this complex contributes to functionalization with biological groups such as the amino acids. The starting materials of amino acids coupling reaction are amino acids esters and the acids esters can return to acids species by $\mathrm{LiOH}$ induced hydrolysis. Therefore, the new exposed carboxylic acid moiety enables the prepared amino acids gold derivatives to continue to couple with a new amine. Owing to belonging to auranofin analogues, these thiolate $\mathrm{Au}(\mathrm{I})$ phosphine complexes containing biological molecules possess potent anticancer properties. A549 (lung carcinoma), Jurkat(T-cell leukaemia) and MiaPaca2 (pancreatic carcinoma) cytotoxicity assays demonstrate that the complexes can inhibit proliferation of tumor cells, with $\mathrm{IC}_{50}$ values as low as in the micromolar range. They also conducted similar assays with several structural modifications in order to establish the structure-activity relationship in this family of complexes, facilitating to the design of new and more potent 
cytotoxic complexes[10]. Subsequently, they found that $\mathrm{Au}(\mathrm{I})$ complexes bearing cysteineinvolving dipeptides exhibited high cytotoxicity, showing a very low $\mathrm{IC}_{50}$ values[11].

Similarly, Akim et al. replaced thiolate part with carbonimidothioates to prepare $\mathrm{Ph}_{3} \mathrm{PAu}[\mathrm{SC}(\mathrm{OR})=\mathrm{NPh}][12]$. They focused on the influence of the $\mathrm{R}$ substituents $[\mathrm{R}=\operatorname{Methyl}(\mathrm{Me})$, Ethyl(Et) and isopropyl(iPr)] upon in vitro cytotoxicity. The compounds are hard to dissolve in water but are soluble in DMSO and acetonitrile. Noteworthily, $\mathrm{Au}-\pi$ interactions emerge in their crystal packing, which play an important role in supermolecular gold chemistry[13]. Those compounds exhibit significant cytotoxicity to the HT-29 cancer cell line. The results of Cytotoxicity assays show that the most active is the Me moiety containing derivative. Several normal cell apoptotic assays demonstrate that the cytotoxicity is responsible for apoptosis and both the extrinsic and intrinsic pathways of apoptosis have emerged. The Me containing compound stimulates the p73 gene, whereas each of Et and iPr activates the p53 gene.
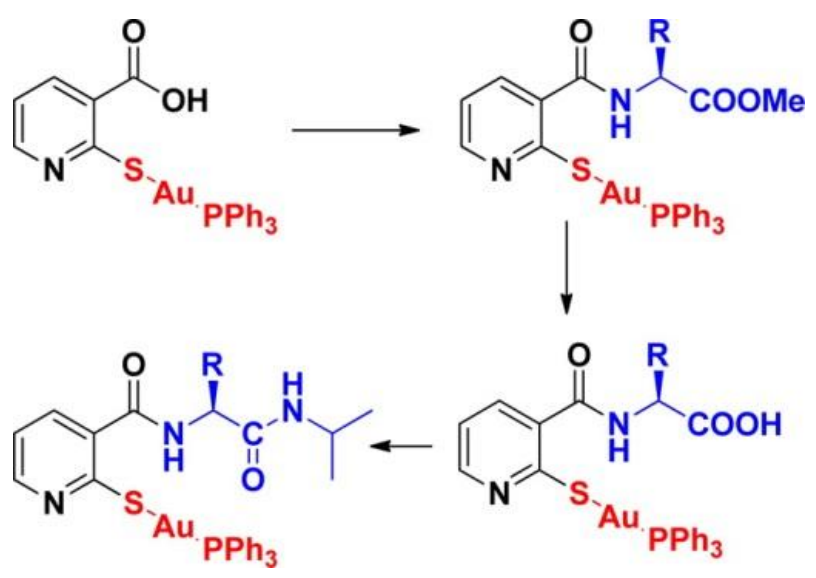

Figure 1. The synthetic scheme of $\mathrm{Au}(\mathrm{I})$ thiolate complexes containing amino acid moieties[9].

Biological activities of a series of DMSOsoluble aminophosphine thiolate $\mathrm{Au}(\mathrm{I})$ complexes [Au(SR)[2-(diphenylphosphinoamino)pyridine]] have been studied by Meireles et al[14]. Antitumor properties of these gold compounds have been tested in vitro against two tumor human cell lines, HeLa (cervical carcinoma) and MCF-7 (mastocarcinoma), using a metabolic activity test (MTT). These different R substitudes containing derivatives show a potent inhibition of thioredoxin reductase (TrxR) activity in HeLa cells. Additionally, the authors conducted a binding study of the $\mathrm{Au}(\mathrm{I})$ complexes with calf thymus (CT-) DNA and different bacterial DNAs. None significant structural changes occurr, although the interactions of complexes with CTDNA have been verified.

Recently, Au(I) alkyne complexes gain increasing medical attentions for their impressive potentials in gold-based drugs. Ott and Rodríguez have investigated a range of DMF-soluble $\mathrm{Au}(\mathrm{I})$ alkyne Triphenylphosphine $\left(\mathrm{PPh}_{3}\right)$ complexes[15], specific targeting to TrxR and thus inhibiting tumor cells proliferation. Further, they examined biological properties of four binuclear $\mathrm{Au}(\mathrm{I})$ alkynyl complexes[16]. Their TrxR inhibition assays of different sizes of bridging ligands suggest a preference for the shorter ones. They also noted that those complexes exhibited strong cytotoxic activities against two different cultured tumor cell lines (MCF-7 and HT-29), albeit insignificant correlation with the activity of TrxR inhibition. Rodríguez reported a synthetic strategy of different $\mathrm{Au}(\mathrm{I})$ complexes with three kinds of propynyloxycoumarins[17]. In this study, they introduced water soluble phosphines to the compounds for the purpose of dissolving in water. Moreover, the following luminescence study indicates that the presence of $\mathrm{Au}(\mathrm{I})$ is responsible for the increase of coumarin phosphorescence emission. In addition, the neutral coumarins containing $\mathrm{Au}(\mathrm{I})$ complexes displayed strong cytotoxic effects on tumor cells, because of high TrxR inhibition ( $\mathrm{IC}_{50}$ values below $0.1 \mu \mathrm{M})$.

As new candidates for chemotherapeutics, $\mathrm{Au}(\mathrm{I}) \mathrm{N}$-heterocyclic carbene (NHC) complexes rapidly bring a wide interest as strong TrxR inhibitors constraining cell proliferation in a wide range of human malignant cell lines effectively. For the purpose of the design of anticancer bioorganometallics, Serebryanskaya synthesized a novel aminotriazole based $\mathrm{NHC} \mathrm{Au}(\mathrm{I})$ complex[18]. Similarly, this compound also can 
stimulate the cytotoxic effects in HT-29 and MDA-MB-231 cancer cells, as the result of TrxR targeting inhibition. Ott and Wölfl detailedly studied the mechanism of $\mathrm{Au}(\mathrm{I}) \mathrm{NHC}$ complexes induced cytotoxicity[19]. Their results reveal that $\mathrm{Au}(\mathrm{I})$ bis(NHC) complexes are able to cause pancreatic cancer cells apoptosis and the resulting cells death can be blocked by the usage of antioxidants, ASK1 siRNA or p38 inhibitor, suggesting that $\mathrm{Au}(\mathrm{I}) \mathrm{NHC}$ complexes promote cell damage and death mainly through the TrxASK1-p38 signal cascade. Their further results suggest that DNA damage may also associate with the compound induced cytotoxicity[20]. Dinda and Saha carefully examined the cytotoxicity of another NHC containing $\mathrm{Au}(\mathrm{I})$ complexes[21]. They found that the gold compound has a wide impact on cytotoxicity related signal ways and can trigger ROS, p53 dependent apoptosis and regulate the expression levels of pro- and anti-apoptotic factors (p53, p21, NF-кB, VEGF and MMP-9). Meanwhile, Hemmert et al. prepared new gold(I) complexes containing two 1-[2-(diethylamino) ethyl]imidazolydene ligands[22], which, particularly, showed a potent selectivity for cancer cells. Che et al. designed a binuclear $\mathrm{Au}(\mathrm{I})$ complex utilizing a bridging bis-NHC ligand to achieve both thiols stability and thiols reactivity[23]. The favorable thiols stability saves this binuclear $\mathrm{Au}(\mathrm{I})$ complex from the attacks of blood thiols, while thiols reactivity guarantees their ability to inhibit TrxR activity. This design can maintain high in vivo efficiency and indeed the in vivo studies reveal appreciable inhibitions of tumor growth in mice bearing HeLa xenograft or mouse B16-F10 melanoma without detectable side-effects supported by the following toxicology studies.

Coordination with other functional ligands pushes the chemotherapeutic development of gold drugs as well. Che et al. have shown that bis-thiolate derived $\mathrm{Au}(\mathrm{I})$ complexes can be attained through the use of thiourea (TU)[24]. The DMSO-soluble two-coordinate $\mathrm{Au}(\mathrm{I})$ complexes have been obtained using N,N'disubstituted imidazolidine-2-thione and $[\mathrm{Au}(\mathrm{THT}) \mathrm{Cl}](\mathrm{THT}=$ tetrahydrothiophene $)$. The nearest $\mathrm{Au}-\mathrm{Au}$ distance in $\mathrm{Au}(\mathrm{I}) \mathrm{TU}$ complexes was over $3.29 \mathrm{~A}^{\circ}$, suggesting the absence of significant intermolecular metal-metal interactions. This compound also exhibits significant cytotoxicity to cancer cells. Particularly, the gold complexes tightly bind TrxR and thus inhibit the activity of TrxR at nanomolar range. With ligand exchange reaction, Corbi et al. synthesized a new gold complex [AuCN $\left.\left(\mathrm{C}_{3} \mathrm{H}_{5} \mathrm{NS}_{2}\right)\right]$ with 2-mercaptothiazoline (MTZ)[25]. The prepared complex is soluble in DMSO and be utilized for evaluation of the cytotoxic effect using HeLa cells, inducing $85 \%$ cell death at a level of $2.0 \mu \mathrm{mol} / \mathrm{L}$. Berners-Price et al. successfully prepared a novel $\mathrm{Au}(\mathrm{I})$ phosphine complexes [Au(d2pype)2]Cl, [(d2pype $=\quad$ 1,2-bis(di-2-pyridylphosphinoethane)][26], showing selectively toxicity to tumorigenic cells. Further, untilizing nano-scale secondary ion mass spectrometry (NanoSIMS), they could visualize the distribution of gold in situ in human breast cancer cells in subcellular range for the first time. According their NanoSIMS ion map, $2 \mathrm{~h}$ treatment with $\left[\mathrm{Au}(\mathrm{d} 2 \mathrm{pype})_{2}\right] \mathrm{Cl}$, the gold mainly distribute in sulfur-rich regions in the nucleus and cytoplasm, supporting the evidence of tight binding inhibition of sulfur-rich protein, such as TrxR.

\section{Antibacterial study of $\mathrm{Au}(\mathrm{I})$ complexes}

Due to the increasingly demands of antibacterial materials, new metallopharmaceutical compounds have been a new and interesting alternative way to develop effective antibacterial agents. Recently, Corbi et al. utilized potassium dicyanoaurate(I) as gold sources to synthesize a series of $\mathrm{Au}(\mathrm{I})$ complex of antibacterial activity via the synthetic strategy of ligand exchange. They selected four different biological function molecules including MTZ (a precursor for a variety of biologically active molecules)[25], rimantadine (a pharmaceutical agent)[27], N-acetyl-L-cysteine (a natural sulfurcontaining amino acid)[28], ibuprofen (an antiinflammatory drug utilized as a cyclooxygenase inhibitor)[29] as the ligands of $\mathrm{Au}(\mathrm{I})$ coordination, separately. The synthetic protocols are simple and convenient. After simple mixture of ligands and gold sources, the solutions 
undergo gentle stirring in aqueous states at room temperature. The products are insoluble in water, possibly due to their polymeric structures, but they are easy to disperse in DMSO. Antibiogram assays indicate that all of the four complexes display effective antibacterial activity against both Gram-negative and Gram-positive microorganisms.

Water solubility has been considered of main interest in the development of both $\mathrm{Au}(\mathrm{I}) \mathrm{NHC}$ complexes as therapeutic agents[30]. Silbestri et al. prepared a variety of water-soluble $\mathrm{Au}(\mathrm{I})$ NHC complexes and investigated their antibacterial properties[30]. The antibacterial results by agar diffusion and broth macrodilution methods evince the antimicrobial ability of these complexes against both Gram- and Gram+ bacterial strains. Particularly, the antibacterial activity of some of these compounds is comparable with AgNO3. Gimeno et al. reported the synthesis of new $\mathrm{Au}(\mathrm{I})$ complexes with aminophosphane ligands and studied their antibacterial activity against Gram-negative and Escherichia coli and Gram-positive pathogens[31]. The bactericidal assays reveal that these compounds show a moderate antimicrobial activity on model Gram-negative and Grampositive microorganisms and those in the absence of $\mathrm{PPh} 3$ moieties display significantly comparable bactericidal capabilities with the referencing antibiotics.

\section{Bioimaging study of $\mathrm{Au}(\mathrm{I})$ complexes}

In recent years, although a detailed insight into chemotherapeutic mechanisms of the $\mathrm{Au}(\mathrm{I})$ complexes is provided, the understanding of the cellular uptake and intracellular distribution of $\mathrm{Au}(\mathrm{I})$ complexes is lacked. Au(I) complexes have for long been known to possess metal-metal interaction generated luminescence properties, which are suitable for the biological imaging with confocal fluorescence microscopy (CFM). However, almost all of the earlier identified $\mathrm{Au}(\mathrm{I})$ complexes do not emit luminescence in the requisite solution states. Therefore, at present, the advances in cellular imaging of $\mathrm{Au}(\mathrm{I})$ complexes mainly focus on non-CFM mapping and CFM by the formation of fluorophores tagged $\mathrm{Au}(\mathrm{I})$ complexes or bimetallic cluster complexes.

As previously mentioned, Price et al. have technically applicated the combination of NanoSIMS and energy filtered transmission electron microscopy (EF-TEM) to mapping $\mathrm{Au}(\mathrm{I})$ complexes[26]. After administration of human breast adenocarcinoma cells with target gold compounds, NanoSIMS ion maps achieve visualization of the morphology of cells and distribution of gold synchronously, while EFTEM can be utilized to observe cellular nuclear and mitochondrial morphology with excellent spatial resolution and its elemental maps are comparable with the results of NanoSIMS.

Although non-CFM maps exhibit potent advantages in $\mathrm{Au}(\mathrm{I})$ complexes imaging, the requirements of high-cost equipment are not available in most of laboratories. Therefore, synthesis of new luminescence emission $\mathrm{Au}(\mathrm{I})$ complexes seems to be a feasible way for gold compounds imaging. Coogan and Pope equiped alkynyl $\mathrm{Au}(\mathrm{I})$ complexes with fluorescent anthraquinone[32]. They prepared a series of mono- and bi-metallic $\mathrm{Au}(\mathrm{I}) \mathrm{PPh}_{3}$ complexes bearing 1,2-, 1,4-, and 1,8dialkynyloxyanthraquinone. Those compounds can well dissolve in DMSO, maintaining their anthraquinone based fluorescence. The administration of anthraquino containing $\mathrm{Au}(\mathrm{I})$ compounds can accordingly induce a significant cytotoxic behavior to MCF-7 carcinoma cell line. Then, CFM study with detection range from 530 to $580 \mathrm{~nm}$ is perform and the images show that the majority of gold compound distribute in cytoplasm, which allowed their successful access plasm organelles, supporting the gold-based drug cytotoxic mechanisms of mitochondrial inhibition.

Rhenmium(Re) complexes have also gained increasing attention for their promising use as imaging agents, due to their excellent photophysical properties and kinetic inertness. To trigger a synergic effect on both the excellent photophysical properties of Re complexes and the good anticancer activity of $\mathrm{Au}(\mathrm{I})$ complexes, Gimeno successfully developed a biheterometallic compound $f a c-\left[\operatorname{Re}(\right.$ bipy $)(\mathrm{CO})_{3}(\mathrm{~L}-$ $\left.\left.\mathrm{AuPPh}_{3}\right)\right][33]$. Cytotoxicity studies are 
performed in human A549 lung cancer cells and the values of $\mathrm{IC}_{50}$ in heterometallic $\operatorname{Re}(\mathrm{I}) / \mathrm{Au}(\mathrm{I})$ derivatives group are over 10-fold less than their sister $\operatorname{Re}(\mathrm{I})$ complexes, suggesting the importance of the alkynyl-phosphine-gold staple for the purpose of efficient chemotherapeutic compounds. CFM records the distribution of the two Re involving luminescent complexes and the maps indicate that the bimetallic derivatives show a much wider interaction range of from mitochondria to the nucleus and even nucleolus than monometallic $\operatorname{Re}(\mathrm{I})$ species which only show general cytoplasmic mitochondrial accumulation. The imaging results indicate a completely different localization pattern for bimetallic species and also reveal that these species can serve as excellent partners in cell imaging and cancer therapy.

Ideally, the emission of functional complexes should be distinguished from the general shortlifetime biological background fluorescent emission. Fluorescence lifetime imaging microscopy (FLIM) could exactly fulfil that demand. The FLIM image is able to reveal the cellular uptake process of $\mathrm{Au}(\mathrm{I})$ complexes and provides information on changes in the intracellular microenvironment. Li et al. reported a cluster structure new heterometallic $\mathrm{Ag}(\mathrm{I})-\mathrm{Au}(\mathrm{I})$ complex $\quad\left[\mathrm{CAu}_{6} \mathrm{Ag}_{2}(\mathrm{dppy})_{6}\right]\left(\mathrm{BF}_{4}\right)_{4} \quad$ with phosphorescent emissive features and excellent photostability[34]. This complex possesses a photoluminescent lifetime $(\sim 32 \mu \mathrm{s})$ which exactly conforms to the demands as a probe in applications of FLIM. They clearly observed that the courses of cellular uptake of the cluster complexes completed within 10 min through an energy dependent and non-endocytic way. The high levels of the complex in the nucleolus identified via inductively coupled plasma atomic emission spectroscopy (ICP-AES) and transmission electron microscopy coupled with an energy dispersive X-ray analysis (TEMEDXA), indicate the possible accumulation of the gold compound in the nucleolus. These results give us a hint that solution state emission gold complexes possess promising potential for high revolution and qualitative imaging of nucleolus in living cells.

\section{Sensing study of $\mathrm{Au}(\mathrm{I})$ complexes}

In contract to the appreciable development of $\mathrm{Au}(\mathrm{I})$ complexes in anticancer study, recent sensing researches of $\mathrm{Au}(\mathrm{I})$ complexes, especially those obtained by organic synthesis, seems to be numbered. Probably, the poor aqueous solubility and the solution state induced quenching suppress their development in sensing application. However, the $\operatorname{Au}(\mathrm{I})$ compounds based sensors performing in organic solvent, such as vapor sensor, are still available. Catalano et al. prepared a heterometallic $\mathrm{Au}(\mathrm{I})-\mathrm{Cu}(\mathrm{I}) \mathrm{NHC}$ complexes. The compounds can reversibly convert between $\mathrm{MeCN}-$ and $\mathrm{MeOH}$-containing forms through ligand exchange reactions, exhibiting tunable luminescent vapochromic behavior. The featured luminescence properties allow the vapors sensing for different solvents, including $\mathrm{MeCN}, \mathrm{H}_{2} \mathrm{O}$, $\mathrm{MeOH}$, and $\mathrm{Me}_{2} \mathrm{CO}$. Mechanism assays demonstrate that the copper coordination number depending changes of $\mathrm{Au}(\mathrm{I})-\mathrm{Cu}(\mathrm{I})$ closed-shell interaction are responsible for vapor-induced ligands exchange and resulting luminescent chromic behavior.

The fascinating $\mathrm{Au}-\mathrm{Au}$ interaction induced luminescence phenomena are well-known facts that play an important part for supermolecular structure construction, self-assembly and luminescence properties. Albeit leaking in aqueous state, emissive properties of some $\mathrm{Au}(\mathrm{I})$ compounds in organic solvent still can be well preserved. Yam et al. developed a high selective $\mathrm{Al}^{3+}$ sensor based on a bis-alkynyl calix[4]arene $\mathrm{Au}(\mathrm{I})$ isocyanide complex[35]. The complex can well dissolve in $\mathrm{CH}_{2} \mathrm{Cl}_{2}-\mathrm{MeCN}$ mixture solvent and its emission band centers at 448-478 nm, originating from a mixture of triplet states arising from a metal-perturbed intra-ligand transition and ligand-to-ligand charge transfer transition. Upon introduction of $\mathrm{Al}^{3+}$, the changes of the complexes in UV-vis absorption indicate the formation of a new chemical derivatives, probably $\mathrm{Al}^{3+}$ bearing adduct. The subsequent computational studies confirm the structure of the $\mathrm{Al}^{3+}$ binding $\mathrm{Au}(\mathrm{I})$ complex and the results show the trivalent $\mathrm{Al}^{3+}$ ion coordinates with two ether, two phenolic and two carbonyl oxygen atoms from the two amide moieties in a trigonal- 
prismatic geometry shape, further identified by ${ }^{1} \mathrm{H}-\mathrm{NMR}$ spectroscopy. The ion-induced structure changes accordingly facilitate the aurophilic interactions which produce a bright orange-red emission when exciting at the absorbance peak of $375 \mathrm{~nm}$, suggesting a potent potential for $\mathrm{Al}^{3+}$ detection. The limit of detection (LOD) can arrive at $0.1 \mu \mathrm{M}$ with excellent selectivity against common metal ions. Liu et al. reported a $\mathrm{Hg}^{2+}$ sensor based on the bimetallic alkyne-Au(I)fluorobenzene complex that possesses AIE in $\mathrm{MeCN}$-water mixture solution[36]. The yellowish-green AIE can be enhanced with sacrificing the solubility by the increase of the fragment of water. The emission can be quenched by $\mathrm{Hg}^{2+}$ selectively against conmen metal ions and provides luminescent decreasing response according to the amount of added $\mathrm{Hg}^{2+}$ in range of $0-20 \mu \mathrm{M}$. The quenching mechanism is reported to be ascribed to the de-aggregation induced by $\mathrm{Hg}^{2+}$, supported by the results of dynamic light scattering measurements.
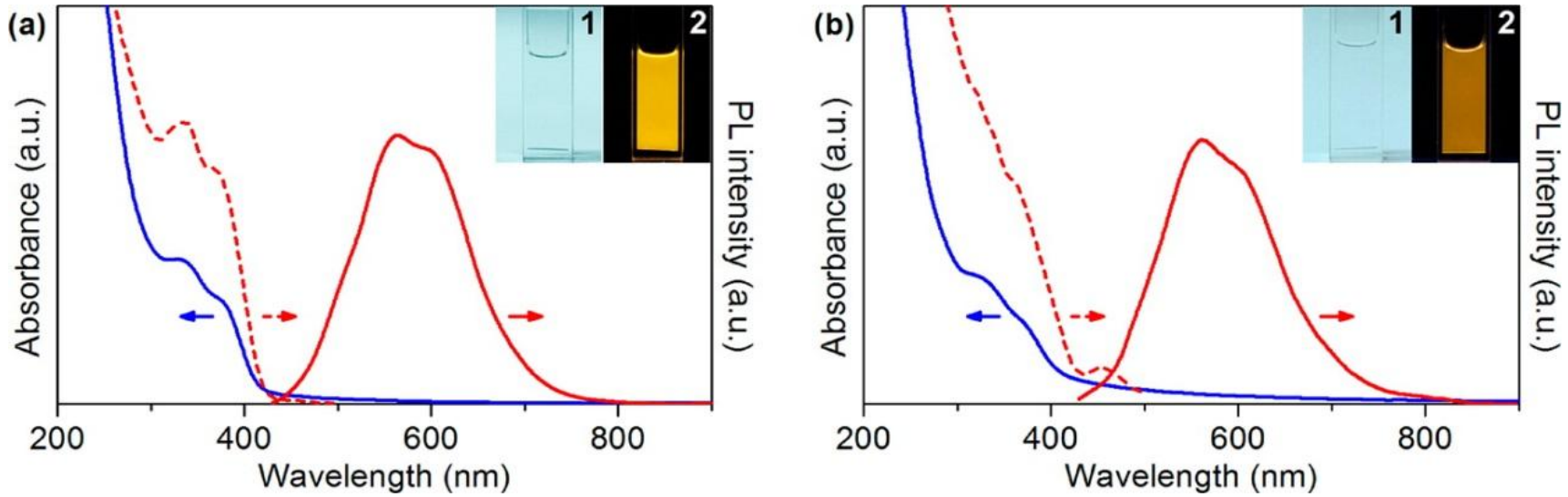

Figure 2. UV-vis absorption (solid blue lines), photoemission (solid red lines), and photoexcitation (dotted red lines) spectra of $\mathrm{Au}(\mathrm{I})-\mathrm{GSH}$ complexes aggregated by (a) ethanol (95\% ethanol by volume) and (b) $\mathrm{Cd}^{2+}$ ions. (Insets) Digital photos of aggregated complexes under (1) visible and (2) UV light[3].

Interestingly, recent growing organic solvent free synthesis (green synthesis) strategies have been proposed, particularly, in sensing application. Green synthesis has so far gained a wide range of attention due to its simple, safe and effective protocols. Lately, some papers reported that thiols could serve as both ligands and reductants in the synthesis of $\mathrm{Au}(\mathrm{I})$ complexes from $\mathrm{Au}(\mathrm{III})$ compounds, such as, aqueous soluble innoxious chloroauric acid, which avoid the utilization of cyanide coordinated gold sources. Through carefully controlling the amount of glutathione (GSH) and reaction temperature, Xie et al. are able to synthesis either mixed valence gold nanoclusters or $\mathrm{Au}(\mathrm{I})$ complexes from the same starting materials in aqueous solution[3]. The whole formation of $\mathrm{Au}(\mathrm{I})-\mathrm{GSH}$ complexes involve two stages. The first stage is the reduction of $\mathrm{Au}(\mathrm{III})$ to $\mathrm{Au}(\mathrm{I})$ and the successive coordination of $\mathrm{Au}(\mathrm{I})$ by GSH. At this stage, the reacting $\mathrm{pH}$ was around the isoelectric point of GSH, resulting in the production of insoluble aggregates. The second stage is initiated by introducing $\mathrm{NaOH}$ to $\mathrm{pH} 7.0$, comprising the dissolution and oligomerization of $\mathrm{Au}(\mathrm{I})-\mathrm{GSH}$ complexes, respectively. The final products are mixtures of $\mathrm{Au}_{10-12} \mathrm{SG}_{10-12}$ species and the largest species is $\left[\mathrm{Au}_{12} \mathrm{SG}_{11}\right]^{+}$. Recalling the earlier mentioned AIE phenomenon, the $\mathrm{Au}(\mathrm{I})-\mathrm{GSH}$ complexes emit a bright yellow light upon the addition of aggregative inducer, such as ethanol or metal cation, as shown in Fig.2. The augmentation of ethanol fragment in the water/ethanol mixture solution can trigger the intra- and inter-aggregation of the water-soluble $\mathrm{Au}(\mathrm{I})-\mathrm{GSH}$ complexes and thus facilitate to the 
$\mathrm{Au}-\mathrm{Au}$ bonding interactions, resulting in metalcentered triplet state luminescence emission $(\sim 2$ $\mu \mathrm{s})$. Similarly, metal ions, for instance, $\mathrm{Cd}^{2+}$, are able to chelate with the amino and carboxyl group of GSH ligands and the addition of $\mathrm{Cd}^{2+}$ accordingly lead to the formation of gold containing aggregates, emitting a bright yellow light. Ling and Cao developed a $\mathrm{Pb}^{2+}$ sensor with the usage of the $\mathrm{Au}(\mathrm{I})-\mathrm{GSH}$ complexes[37]. Considering the interference by other transitional metal ion, they designed an indirect emission enhancement strategy that they first produced the AIE probe with the addition of $\mathrm{Zn}^{2+}$ into the $\mathrm{Au}(\mathrm{I})-\mathrm{GSH}$ complexes solution and then the emission of AIE probe was further enhanced by the addition of target analyte, $\mathrm{Pb}^{2+}$. The results of the AIE probe optimization experiments also demonstrate that the aggregation induced by $\mathrm{Zn}^{2+}$ is more stable, compared with other cationic inducer, such as $\mathrm{Cd}^{2+}$ and $\mathrm{Pb}^{2+}$. With this luminescence probe, they constructed a $\mathrm{Pb}^{2+}$ sensor with linear range in concentration from 2 to $40 \mu \mathrm{M}$, with reliable performance in real water samples.

Besides GSH, cysteine, another endogenous thiol compound, can also be utilized as both the ligand and the reductant in the preparation of Au(I) complexes. Pei et al. successfully synthesized $\mathrm{Au}(\mathrm{I})-\mathrm{Cys}$ complexes using similar methods[4]. They harvested $\left[\mathrm{Au}_{6} \mathrm{Cys}_{7}\right]^{+}$as the main composition of the product, which also showed pH-dependent aqueous solubility. Analogous with EDTA chelator, Cys coordinated complexes allow a stronger interaction with a range of metal ion, including $\mathrm{Ca}^{2+}$. Based on the AIE of $\mathrm{Au}(\mathrm{I})-\mathrm{Cys}$ complexes via the introduction of $\mathrm{Ca}^{2+}$, a label-free luminescence sensor for $\mathrm{Ca}^{2+}$ is developed. However, the carboxyl and amino group interaction with metal cation based probe shows poor selectivity for $\mathrm{Ca}^{2+}$ and several other divalent metal ions, including $\mathrm{Ba}^{2+}, \mathrm{Cu}^{2+}, \mathrm{Mg}^{2+}$, $\mathrm{Pb}^{2+}$ and $\mathrm{Zn}^{2+}$. To remove the existing inference, riethylenetetramine(TETA) is employed as the making agent against $\mathrm{Cu}^{2+}, \mathrm{Pb}^{2+}$ and $\mathrm{Zn}^{2+}$. The following adjustment of $\mathrm{pH}$ to 11.5 with sulfuric acid avoids the inference from $\mathrm{Mg}^{2+}$ and $\mathrm{Ba}^{2+}$ via the formation of insoluble $\mathrm{Mg}(\mathrm{OH})_{2}$ and $\mathrm{BaSO}_{4}$ precipitates. Therefore, a super selective method for visual detection of $\mathrm{Ca}^{2+}$ is established with linear relationship in concentration range from 50 to $300 \mu \mathrm{M}$ and appreciable feasibility of usage in real samples, for instant, lake water, fetal bovine serum and milk.

Some artificial thiols, such as 3-Mercapto1,2,4-triazole (MTA), are similarly capable of reducing $\mathrm{Au}(\mathrm{III})$ to $\mathrm{Au}(\mathrm{I})$ and coordinating with $\mathrm{Au}(\mathrm{I})$ by the formation of oligomeric $\mathrm{Au}(\mathrm{I})$ thiolates complexes. Due to better solubility of MTA in ethanol than water, $\mathrm{Lu}$ et al. mixed ethanol dissolving MTA with aqueous $\mathrm{HAuCl}_{4}$, producing high quality of $\mathrm{Au}(\mathrm{I})-\mathrm{MTA}$ complexes[38]. MALDI-TOF-MS assays demonstrate that the oligomeric $[\mathrm{Au}(\mathrm{I}) \mathrm{MTA}]_{3}$ mainly constitute the products. Either in DMF solution state or in solid state, the gold compounds display a bright red emission with quantum yield of $38 \%$. The probable electronic metallic triplet-state contributes to the phosphorescent emission of $\mathrm{Au}(\mathrm{I})$-MTA complexes with a large Stokes shift of over 200 $\mathrm{nm}$ and an average lifetime of $10 \mu \mathrm{s}$ at room temperature. These distinctive phosphorescent features of $\mathrm{Au}(\mathrm{I})-\mathrm{MTA}$ complexes enable itself an excellent probe for cyanide detection. The LOD of this sensor can achieve a level of $80 \mathrm{nM}$ with the linear relationship in concentration range from 0.16 to $50 \mu \mathrm{M}$. As for the selectivity, only $\mathrm{S}^{2-}$ interferes the phosphorescent signal of detection, which can be masked by introducing $\mathrm{H}_{2} \mathrm{O}_{2}$. Interestingly, in the concern of the solid state emission, they fabricated a phosphorescent macroporous film with $\mathrm{Au}(\mathrm{I})$ complexes for the first time and applicated this film sensor for colorimetric determination of cyanide in real samples, including red wine, coffee, juice, soil and even cassava. As above, solid or aggregates emission properties endow $\mathrm{Au}(\mathrm{I})$ complexes with promising potentials for film based sensor. Tedford et al. successfully fabricated a robust thin-film oxygen sensors by immobilization of a lipophilic, blue-green emissive polynuclear gold(I) complex, bis[m(bis(diphenylphosphino)octadecylamine-P,P)] dichlorodigold(I), with oxygen permeable polystyrene and ormosil matrices[39]. The bright phosphorescence emission of the gold compound can be quenched by gaseous and dissolved oxygen. The functional film can stay in water 
without leaching for a period of $8 \mathrm{~h}$. Particularly, the oxygen induced phosphorescence quenching can be recovered completely with fast response time, indicating the fabrication of a recyclable and reversible thin-film sensor.

Besides aurophilic interaction based luminescence, other non-photophysics properties of $\mathrm{Au}(\mathrm{I})$ complexes can also be used to construct sensors. On accounts of the changeable chemical valence between $\mathrm{Au}(\mathrm{I})$ and $\mathrm{Au}(\mathrm{III})$ via reduction or oxidation, Srivastava et al. developed a electrochemistry sensor with imidazole-based NHC-Au(I) complexes for glucose analysis[40]. The mechanism of glucose detection can be concluded in two steps: Firstly, electrocatalytic oxidation from $\mathrm{Au}(\mathrm{I})$ to $\mathrm{Au}(\mathrm{III})$ occur at NHC$\mathrm{Au}(\mathrm{I})$-modified electrodes in the voltage increase procedure; And second step is the reduction from $\mathrm{Au}(\mathrm{III})$ to $\mathrm{Au}(\mathrm{I})$ by glucose. The NHC-Au(I)modified electrode is anti-interference from other species coexisting in blood such as uric acid, and is further utilized to determine the blood glucose level in real serum samples with satisfied precision. Interestingly, based on the well-known specify-affinity metallophilic interaction between $\mathrm{Hg}$ (II) and $\mathrm{Au}(\mathrm{I})$, Zhang et al. developed a novel electrochemistry sensor modified with $\mathrm{Au}(\mathrm{I})$ alkanethiolate nanotubes for the $\mathrm{Hg}^{2+}$ detection[41]. Due to the super-hydrophobic properties, $\mathrm{Au}(\mathrm{I})$ alkanethiolate nanotubes modified glassy carbon electrode are encapsulated with nafion matrices for the enhancement of immobilizing stability. The novel $\mathrm{Au}(\mathrm{I})$ nanostructure based sensor with LOD of $0.5 \mathrm{nM}$ exhibits two linear relationships in the concentration range of $1-100 \mathrm{nM}$ and 100-1000 $\mathrm{nM}$ respectively. Due to the advantages of convenience, costeffectivity and fast detection, this electrochemical method possesses potent potentials for health related and environmental $\mathrm{Hg}^{2+}$ detection.

\section{Conclusion and outlook}

Last two decades witness great advances in synthesis and application of $\mathrm{Au}(\mathrm{I})$ complexes. This review focused and summarized recent five years efforts on the development of $\mathrm{Au}(\mathrm{I})$ complexes with various biological applications.
Four selected biology related areas based on $\mathrm{Au}(\mathrm{I})$ complexes have been discussed and explored.

Gold-thiol containing protein interactions have been evidenced to be key issue for $\mathrm{Au}(\mathrm{I})$ complexes in regards of their chemotherapeutic effects. Prior to their binding to targets, chemical and biological stability should be guaranteed by the selection of suitable ligands. Besides traditional ligands, such as thiolate, phosphine and cyanide, several new members, including alkyne, NHC and fluorobenzence, are gaining more and more attention for their biological stability and structural richness. Meanwhile, the chemotherapeutic effects, mainly anticancer, have been detailed analyzed. DNA and protein assays demonstrate that the formation of goldthiolate enzyme adducts are the direct reason for cells apoptosis and death. In order to holistic understanding the uptake of cells and subcellular distribution of gold compounds, plenty of imaging techniques have been adopted. The maps of NanoSIMS and EFTEM observe that gold complexes distribute in thiols-rich region in cytoplasm and nucleus. Indeed, anticancer capability of $\mathrm{Au}(\mathrm{I})$ has been careful explored and evidenced from cellular to subcellular levels. However, in vivo anticancer study of $\mathrm{Au}(\mathrm{I})$ complexes is quite insufficient and their sideeffects still stay ambiguous. Great efforts should be exerted for a comprehensive biological assessment of $\mathrm{Au}(\mathrm{I})$ complexes.

As for the antibacterial activity, the recent attentions are focused on the materials preparation and routine antibacterial assay. However, the antibacterial mechanism is rarely concerned, thus limiting the development of the $\mathrm{Au}(\mathrm{I})$ complexes in antibacterial. In addition, among the antibacterial technologies based on $\mathrm{Au}(\mathrm{I})$ complexes, simple solution mixture is the most frequent method. In this regard, various nanotechnologies and nanomaterials, such as micro-/nano-carriers, can be applied to improve the antibacterial activities.

The advances of $\mathrm{Au}(\mathrm{I})$ complexes in imaging, especially in CFM, are associated with ligands. Either organic or metallic fluorophores can facilitate to the usage of CFM and thus the distribution of gold compounds can be observed. 
However, the imaging studies based on the emission from gold are quite rare, although $\mathrm{Au}(\mathrm{I})$ complexes are able to emit phosphorescence featured light with high quantum yields, as the results of $\mathrm{Au}-\mathrm{Au}$ binding interaction. The scarcity for the $\mathrm{Au}(\mathrm{I})$ moiety induced luminescence imaging are possibly ascribe to dissolving state associated quenching of $\mathrm{Au}(\mathrm{I})$ complexes. Therefore, the synthesis of $\mathrm{Au}(\mathrm{I})$ complexes capable of aqueous emission is essential for the development of $\mathrm{Au}(\mathrm{I})$ complexes in bioimaging. In this concern, di- and poly- nuclear gold compounds could be promising candidates for in vivo and in vitro bioimaging. The multinuclear $\mathrm{Au}(\mathrm{I})$ complexes can form cluster accumulation structure or intra-aggregates induced by small molecules, which shall not increase the size of the complexes and resulting produce insoluble precipitates.

Recent $\mathrm{Au}(\mathrm{I})$ complexes based sensing technologies are mainly applicated in metal ion detection. Indeed, applausively, the AIE concept has been introduced to the $\mathrm{Au}-\mathrm{Au}$ bonding generated emission, which extend the understanding and application of $\mathrm{Au}(\mathrm{I})$ complexes in sensing design. However, rare reports involve the detection of physiological small molecule and other important health science related compounds. Therefore, the novel materials and design should be proposed in order to fulfill the demands for sensing a wider range of analytes.

\section{Acknowledgements}

The work is supported by National Natural Science Foundation of China (NSFC Grant No. 21475009, 21475008, 21175140, 21073203, 2127007, 21275017), the Fundamental Research Funds for the Central Universities (FRF-TP-15-014A3) and Beijing Higher Education Young Elite Teacher Project (YETP0424). The authors would like to express their sincere appreciation to the Deanship of Scientific Research at King Saud University for its funding of this research through the Research Group Project No. PRG-1436-011.

\section{References}

1. Yu SY, Zhang ZX, Cheng ECC, Li YZ, Yam VWW, Huang HP, Zhang RB. A chiral luminescent AU(16) ring self-assembled from achiral components. Journal of the American Chemical Society 2005; 127 (51): 1799417995. DOI: $10.1021 / \mathrm{Ja} 0565727$

2. Pucci A, Iasilli G, Tantussi F, Fuso F, Ruggeri G. Aggregation Induced Emission as a new Tool for Polymer Traceability. 6th International Conference on Times of Polymers (Top) and Composites 2012; 1459: 89-91. DOI:10.1063/1.4738407

3. Luo ZT, Yuan X, Yu Y, Zhang QB, Leong DT, Lee JY, Xie JP. From Aggregation-Induced Emission of $\mathrm{Au}(\mathrm{I})$-Thiolate Complexes to Ultrabright Au(0)@Au(I)-Thiolate Core-Shell Nanoclusters. Journal of the American Chemical Society 2012; 134 (40): 1666216670. DOI:10.1021/ja306199p

4. Guo YH, Tong XY, Ji LY, Wang ZL, Wang $\mathrm{HY}, \mathrm{Hu}$ JM, Pei RJ. Visual detection of $\mathrm{Ca} 2+$ based on aggregation-induced emission of $\mathrm{Au}(\mathrm{I})-\mathrm{Cys}$ complexes with superb selectivity. Chemical Communications 2015; 51 (3): 596598. DOI:10.1039/c4cc07592g

5. Hong Y, Lam JWY, Tang BZ. Aggregationinduced emission. Chemical Society Reviews 2011; $40 \quad$ (11): $\quad 5361-5388$. DOI:10.1039/C1CS15113D

6. Luo J, Xie Z, Lam JWY, Cheng L, Chen H, Qiu C, Kwok HS, Zhan X, Liu Y, Zhu D, Tang BZ. Aggregation-induced emission of 1methyl-1,2,3,4,5-pentaphenylsilole. Chemical Communications 2001; (18): 1740-1741. DOI:10.1039/B105159H

7. Assefa Z, Mcburnett BG, Staples RJ, Fackler JP, Assmann B, Angermaier K, Schmidbaur H. Syntheses, Structures, and Spectroscopic Properties of Gold(I) Complexes of 1,3,5Triaza-7-phosphaadamantane (TPA). Correlation of the Supramolecular Au.cntdot. .cntdot. .cntdot.Au Interaction and Photoluminescence for the Species (TPA)AuCl and [(TPA-HCl)AuCl]. Inorganic Chemistry 1995; $34 \quad$ (1): 75-83. DOI:10.1021/ic00105a016

8. Sadler PJ, Guo ZJ. Metal complexes in 
medicine: Design and mechanism of action. Pure and Applied Chemistry 1998; 70 (4): 863-871. DOI: 10.1351/pac199870040863

9. Gutierrez A, Bernal J, Villacampa MD, Cativiela C, Laguna A, Gimeno MC. Synthesis of New Gold(I) Thiolates Containing Amino Acid Moieties with Potential Biological Interest. Inorganic Chemistry 2013; 52 (11): 6473-6480. DOI:10.1021/ic4003803

10. Gutierrez A, Gracia-Fleta L, Marzo I, Cativiela C, Laguna A, Gimeno MC. Gold(I) thiolates containing amino acid moieties. Cytotoxicity and structure-activity relationship studies. Dalton Transactions 2014; $43 \quad$ (45): $\quad$ 17054-17066. DOI:10.1039/c4dt02299h

11. Gutierrez A, Marzo I, Cativiela C, Laguna A, Gimeno MC. Highly Cytotoxic Bioconjugated Gold(I) Complexes with Cysteine-Containing Dipeptides. Chemistry-a European Journal 2015; 21 (31): 1108811095. DOI: $10.1002 /$ chem. 201501458

12. Yeo CI, Ooi KK, Akim AM, Ang KP, Fairuz ZA, Halim SNBA, Ng SW, Seng HL, Tiekink ERT. The influence of $R$ substituents in triphenylphosphinegold(I) carbonimidothioates, $\mathrm{Ph} 3 \mathrm{PAu}[\mathrm{SC}(\mathrm{OR})=\mathrm{NPh}]$ $(\mathrm{R}=\mathrm{Me}$, Et and $\mathrm{iPr})$, upon in vitro cytotoxicity against the HT-29 colon cancer cell line and upon apoptotic pathways. Journal of Inorganic Biochemistry 2013; 127 : 24-38. DOI:10.1016/j.jinorgbio.2013.05.011

13. Tiekink ERT, Zukerman-Schpector J. Gold center dot center dot center dot pi aryl interactions as supramolecular synthons. Crystengcomm 2009; 11 (7): 1176-1186. DOI:10.1039/b901576k

14. Ortego L, Cardoso F, Martins S, Fillat MF, Laguna A, Meireles M, Villacampa MD, Gimeno MC. Strong inhibition of thioredoxin reductase by highly cytotoxic gold(I) complexes. DNA binding studies. Journal of Inorganic Biochemistry 2014; 130: 32-37. DOI:10.1016/j.jinorgbio.2013.09.019

15. Meyer A, Bagowski CP, Kokoschka M, Stefanopoulou M, Alborzinia H, Can S, Vlecken DH, Sheldrick WS, Wolfl S, Ott I. On the Biological Properties of Alkynyl
Phosphine Gold(I) Complexes. Angewandte Chemie-International Edition 2012; 51 (35): 8895-8899. DOI:10.1002/anie.201202939

16. Meyer A, Gutierrez A, Ott I, Rodriguez L. Phosphine-bridged dinuclear gold(I) alkynyl complexes: Thioredoxin reductase inhibition and cytotoxicity. Inorganica Chimica Acta 2013; 398: 72-76. DOI:10.1016/j.ica.2012.12.013

17. Arcau J, Andermark V, Aguilo E, Gandioso A, Moro A, Cetina M, Lima JC, Rissanen K, Ott I, Rodriguez L. Luminescent alkynyl-gold(I) coumarin derivatives and their biological activity. Dalton Transactions 2014; 43 (11): 4426-4436. DOI:10.1039/c3dt52594e

18. Serebryanskaya TV, Zolotarev AA, Ott I. A novel aminotriazole-based NHC complex for the design of gold(I) anti-cancer agents: synthesis and biological evaluation. Medchemcomm 2015; 6 (6): 1186-1189. DOI:10.1039/c5md00185d

19. Cheng XL, Holenya P, Can S, Alborzinia H, Rubbiani R, Ott I, Wolfl S. A TrxR inhibiting gold(I) NHC complex induces apoptosis through ASK1-p38-MAPK signaling in pancreatic cancer cells. Molecular Cancer 2014; 13: DOI: 10.1186/1476-4598-13-221

20. Holenya P, Can SZ, Rubbiani R, Alborzinia H, Junger A, Cheng XL, Ott I, Wolfl S. Detailed analysis of pro-apoptotic signaling and metabolic adaptation triggered by a Nheterocyclic carbene-gold(I) complex. Metallomics 2014; 6 (9): 1591-1601. DOI:10.1039/c4mt00075g

21. Nandy A, Dey SK, Das S, Munda RN, Dinda J, Das Saha K. Gold (I) N-heterocyclic carbene complex inhibits mouse melanoma growth by p53 upregulation. Molecular Cancer 2014; 13: DOI: 10.1186/1476-459813-57

22. Boselli L, Ader I, Carraz M, Hemmert C, Cuvillier O, Gornitzka H. Synthesis, structures, and selective toxicity to cancer cells of gold(I) complexes involving $\mathrm{N}$ heterocyclic carbene ligands. European Journal of Medicinal Chemistry 2014; 85: 8794. DOI:10.1016/j.ejmech.2014.07.086

23. Zou TT, Lum CT, Lok CN, To WP, Low KH, Che CM. A Binuclear Gold(I) Complex with 
Mixed Bridging Diphosphine and Bis(NHeterocyclic Carbene) Ligands Shows Favorable Thiol Reactivity and Inhibits Tumor Growth and Angiogenesis In Vivo. Angewandte Chemie-International Edition 2014; $53 \quad$ (23): $5810-5814$. DOI:10.1002/anie.201400142

24. Yan K, Lok CN, Bierla K, Che CM. Gold(I) complex of N,N '-disubstituted cyclic thiourea with in vitro and in vivo anticancer properties-potent tight-binding inhibition of thioredoxin reductase. Chemical Communications 2010; 46 (41): 7691-7693. DOI:10.1039/c0cc01058h

25. Abbehausen C, Castro JF, Spera MBM, Heinrich TA, Costa-Neto CM, Lustri WR, Formiga ALB, Corbi PP. Synthesis, spectroscopic characterization, DFT studies and biological assays of a novel gold(I) complex with 2-mercaptothiazoline. Polyhedron 2011; 30 (13): 2354-2359. DOI:10.1016/i.poly.2011.06.021

26. Wedlock LE, Kilburn MR, Cliff JB, Filgueira L, Saunders M, Berners-Price SJ. Visualising gold inside tumour cells following treatment with an antitumour gold(I) complex. Metallomics 2011; 3 (9): 917-925. DOI:10.1039/c1mt00053e

27. Sucena SF, Paiva REF, Abbehausen C, Mattos IB, Lancellotti M, Formiga ALB, Corbi PP. Chemical, spectroscopic characterization, DFT studies and antibacterial activities in vitro of a new gold(I) complex with rimantadine. Spectrochimica Acta Part aMolecular and Biomolecular Spectroscopy 2012; $\quad 89$ : 114-118. DOI:10.1016/j.saa.2011.12.043

28. Corbi PP, Quintao FA, Ferraresi DKD, Lustri WR, Amaral AC, Massabni AC. Chemical, spectroscopic characterization, and in vitro antibacterial studies of a new gold(I) complex with N-acetyl-L-cysteine. Journal of Coordination Chemistry 2010; 63 (8): 13901397. DOI:10.1080/00958971003782608

29. Fiori ATM, Lustri WR, Magalhaes A, Corbi PP. Chemical, spectroscopic characterization and antibacterial activities in vitro of a novel gold(I)-ibuprofen complex. Inorganic Chemistry Communications 2011; 14 (5):
738-740. DOI:10.1016/j.inoche.2011.02.024

30. Fernandez GA, Gurovic MSV, Olivera NL, Chopa AB, Silbestri GF. Antibacterial properties of water-soluble gold(I) Nheterocyclic carbene complexes. Journal of Inorganic Biochemistry 2014; 135: 54-57. DOI:10.1016/j.jinorgbio.2014.03.001

31. Ortego L, Gonzalo-Asensio J, Laguna A, Villacampa MD, Gimeno MC. (Aminophosphane)gold(I) and silver(I) complexes as antibacterial agents. Journal of Inorganic Biochemistry 2015; 146: 19-27. DOI:10.1016/j.jinorgbio.2015.01.007

32. Balasingham RG, Williams CF, Mottram HJ, Coogan MP, Pope SJA. Gold(I) Complexes Derived from Alkynyloxy-Substituted Anthraquinones: Syntheses, Luminescence, Preliminary Cytotoxicity, and Cell Imaging Studies. Organometallics 2012; 31 (16): 5835-5843. DOI:10.1021/om300475y

33. Fernandez-Moreira V, Marzo I, Gimeno MC. Luminescent $\operatorname{Re}(\mathrm{I})$ and $\operatorname{Re}(\mathrm{I}) / \mathrm{Au}(\mathrm{I})$ complexes as cooperative partners in cell imaging and cancer therapy. Chemical Science 2014; 5 (11): 4434-4446. DOI:10.1039/c4sc01684j

34. Chen M, Lei Z, Feng W, Li CY, Wang QM, Li FY. A phosphorescent silver(I)-gold (I) cluster complex that specifically lights up the nucleolus of living cells with FLIM imaging. Biomaterials 2013; 34 (17): 4284-4295. DOI:10.1016/j.biomaterials.2013.02.032

35. Hau FKW, He XM, Lam WH, Yam VWW. Highly selective ion probe for Al3+ based on $\mathrm{Au}(\mathrm{I})$ center dot center dot center dot $\mathrm{Au}(\mathrm{I})$ interactions in a bis-alkynyl calix[4]arene $\mathrm{Au}(\mathrm{I})$ isocyanide scaffold. Chemical Communications 2011; 47 (31): 8778-8780. DOI:10.1039/c1cc12677f

36. Ma K, Li X, Xu B, Tian WJ. A sensitive and selective "turn-on" fluorescent probe for $\mathrm{Hg} 2+$ based on thymine-Hg2+-thymine complex with an aggregation-induced emission feature. Analytical Methods 2014; 6 (7): 2338-2342. DOI:10.1039/c3ay42255k

37. Liu CJ, Ling J, Zhang XQ, Peng J, Cao QE, Ding ZT. Synergistic aggregating of $\mathrm{Au}(\mathrm{I})$ glutathione complex for fluorescence "turn- 
on" detection of $\mathrm{Pb}(\mathrm{II})$. Analytical Methods 2013; $5 \quad$ (20): $\quad$ 5584-5588. DOI:10.1039/c3ay40823j

38. Zong CH, Zheng LR, He WH, Ren XY, Jiang $\mathrm{CH}, \quad \mathrm{Lu}$ LH. In Situ Formation of Phosphorescent Molecular Gold(I) Cluster in a Macroporous Polymer Film to Achieve Colorimetric Cyanide Sensing. Analytical Chemistry 2014; 86 (3): 1687-1692. DOI:10.1021/ac403480q

39. Mills A, Tommons C, Bailey RT, Crilly P, Tedford MC. Thin-film oxygen sensors using a luminescent polynuclear gold(I) complex. Analytica Chimica Acta 2011; 702 (2): 269273. DOI:10.1016/j.aca.2011.06.059
40. Prathap MUA, Aguilar $\mathrm{CaH}$, Pandiyan T, Srivastava R. Synthesis of imidazole-based $\mathrm{NHC}-\mathrm{Au}(\mathrm{I})$ complexes and their application in non-enzymatic glucose sensing. Journal of Applied Electrochemistry 2013; 43 (9): 939951. DOI:10.1007/s10800-013-0579-5

41. Xie WY, Zhang H, He SX, Tang DY, Fang SX, Huang Y, Du CL, Zhang YX, Zhang W. A novel electrochemical sensor based on nafionstabilized $\mathrm{Au}(\mathrm{I})$-alkanethiolate nanotubes modified glassy carbon electrode for the detection of $\mathrm{Hg} 2+$. Analytical Methods 2014; 6 (14): 4988-4990. DOI:10.1039/c4ay00640b 